\title{
USE OF MECHANISATION INDEX FOR ASSESSING LEVEL OF ENERGY CONSUMPTION IN SOME NEWLY RECLAIMED AGRICULTURAL FARMS.
}

\author{
Khater, M. M. I.*
}

\begin{abstract}
The levels of agricultural mechanization at some farms on the new reclaimed areas of Nubaria in El Behira Governorate were measured and the productivity of each surveyed farms was analyzed. The purpose of this study was to determine the degree, level and capacity index of agricultural mechanization in the district and their relations with productivity. The results of the farm mechanization index revealed that the highest level of mechanization was $62.99 \%$ for the sugar beet area while the lowest mechanization index was $26.53 \%$ for West Nubaria area, while the total productivity ranged between $0.0115 \mathrm{ha} / \mathrm{kW} . \mathrm{h}$ and 0.0557 $\mathrm{ha} / \mathrm{kW}$.h. The average crop yields on maize ranges between 1.2 to 1.7 $\mathrm{Mg} / \mathrm{ha}$ and that of sugar beet ranges between 11 to $13 \mathrm{Mg} / \mathrm{ha}$. The general analysis of the study indicated that high levels in agricultural mechanization policy, existence of favorable conditions for full integration of agricultural mechanization, enough essential infrastructure and financial credits among other variables explained the observed high scale of production (sugar beet area) and vice versa (west Nubaria area).
\end{abstract}

Keywords: Mechanization index, Level of mechanization.

\section{INTRODUCTION}

echanization planning for the new reclaimed areas requires the
quantitative assessment of the mechanization index and its
impact on agricultural production and energy factors (mechanical power, economic advantage and energy ratio). By definition, the mechanization of agriculture is the application of mechanical implements or as a whole, the application of the state-of-the-art technologies in agriculture to increase productivity and to reach sustainable agriculture (Chisango and Dzama 2013).

*Soil Conservation Department, Desert Research Center, Cairo, Egypt 
Several authors have studied the status of mechanization with reference to the intensity of power or energy availability and its impact on increasing the agricultural productivity. Experiences with quantifying the impact of mechanization on agricultural production efficiency in the new reclaimed areas of Egypt are still scarce. Mechanization technology is specific and dynamic; therefore, the quality of mechanization inputs and the land labor productivity may differ considerably (Singh, 2006). He also added that the mechanization index for the rice crop, which occupies the largest area under cultivation, is 0.08 , whereas the mechanization index for wheat is 0.30. (Tabatabaeefar and Omid, 2005) reported that Mechanization planning require the quantitative assessment of the mechanization index and its impact on agricultural production and economic factors. (Bakhshoodeh and Thomson 2001) measured the technical efficiency of wheat producers in Kerman province, Iran, they demonstrated that the level of inefficiency was a function of farm size. In addition, wheat producers may be able to adopt their production process more easily and quickly by implementing new techniques. The mechanization index of the intensive and reduced tillage was calculated to be 33 and 27 (\%), respectively. Moreover, reduced tillage through the use of a conservation tillage system results in cost savings for labor, fuel and time (Ozpinar, 2006). Higher productivity, which requires greater power and mechanization, is one of the most important challenges that can face production when resources are limited. (Deng et al. 2005) have stated that farm machinery contributed to $22-32 \%$ of Chinese agriculture. When the technical efficiency is close to 1 by means of new mechanization methods, the rice production can be increased. (Karimi et al., 2008) reported that there is a major defect in quantifying a mechanization indicator based on the ratio of mechanical tractive farm power to total farm power. While the unit farm power could be considered as indicative of potential power availability, it may not necessarily be fully utilized on the farms. This may depend upon availability of diesel fuel and adequate workload. The majority of the farmers in developing countries use tractors for transport of agricultural and non-agricultural commodities. (Olaoye 2007) reported that agricultural mechanization as a system 
engineering requires certain environmental, agricultural, social and economic conditions. He added that, mechanization technologies and their sustainable use such as tillage, planting, weeding and harvesting are critical factors where affordable labour is insufficient to permit timely operation. Other key factors that influence successful mechanization include Socio-economic factors, supporting infrastructure, land and other agro-ecological conditions, technical skills and service. Up till now, The new reclaimed areas were not able to define the role of sustainable agricultural mechanization that can transform the experimental phase presently existing in the farms schemes. The new reclaimed areas can achieve goals through accelerated food production by increasing both labor and land productivity as well as expanding areas of cultivated land.

Therefore, the present research aimed to determine the levels of mechanization for sugar beet and Maize producers, focusing on the impact of mechanization on production and investigate the extent of which crop production can be improved under existing technologies.

\section{MATERIALS AND METHODS}

The research survey was undertaken in Nubaria region in El Behira Governorate which covers an area of approximately $3992.6 \mathrm{~km}^{2}$ (http://www.agricultureegypt.com/ 2011) and is situated in the west of delta. The region usually experiences a dry climate and temperature on the whole, ranging between 42.6 in summer and $10.6^{\circ} \mathrm{C}$ in winter seasons. The annual rainfall on an average has been reported as $116.9 \mathrm{~mm}$. This province has 5 townships (Sugar beet, El Nahda, West Nubaria, El Bostan and South El Tahrir).

The data used in this study were collected through actual field experiments for both sugar beet and Maize. In addition, another data were collected during a survey covering the crop year of 2010 . Information from many farms were collected through repeated visits. The data covered information on farm mechanization activities as well as other farm activities included human labor, farm production, crop output and prices of agricultural services. 
The machinery practices were separated into three stages: tillage, planting and harvesting. Furthermore, an investigation of the impact of mechanization on productivity and efficiency requires precise data. Many studies have used man-days or person-days to measure labor factor (Rahman and Hasan, 2008), but the work of the labors ranged from 6 to 10 hours per day; moreover, the labor inputs were measured based on the energy equivalent. The machinery operations with different capacities based on the hours performed.

The practice of selective mechanization was prominent in all selected farms. Agricultural mechanization operations were restricted only to tillage operations such as plowing, planting and harvesting.

The collected data included available tractors and different farm machineries. Different implements and machineries in collected data are as follows:

1- Tillage implements ( Plows and disc harrows)

2- Sowing implements (Seed drills and planters)

3- Harvesting implements ( harvesters)

\section{Field operations:}

Primary data were collected through primary survey which covered the general background information of the selected farms, technical parameters involved in management techniques, land preparation/tillage, planting and harvesting operations. Some interactive interviews with the agricultural engineers, agronomists, extension engineers and farmers in groups at all the farm settlements were conducted before other individual interviews. Various indices of agricultural mechanization and productivity were defined for the purpose of the investigation.

\section{Measurement of agricultural mechanization index}

\section{1- Degree of agricultural mechanization}

According to (Nowacki 1974), the assessment of the grading of the level of mechanization was: hand tools (M1), animal drawn (M2) and Tractorized (M3). For the purpose of this research study, the index of 
mechanization is limited to the available power sources in the Nubaria zone by (M1 and M3). The degrees of mechanization at the two available power sources were defined as follows:

Degree of Mechanization M1 is the average energy input of work provided exclusively by human power per hectare: as described by (Nowacki 1974).

\section{LH = 0.07. NH. TH $/$ A.....................(1)}

where, $\mathrm{LH}=$ average energy input or work provided per hectare by human labor $(\mathrm{kW} . \mathrm{h} / \mathrm{ha})$; $\mathrm{NH}=$ average number of labor employed $(\mathrm{kW} . \mathrm{h} / \mathrm{ha}) ; \mathrm{TH}=$ average rated working time devoted to manual operation; $0.07=$ Theoretical average power of an average man working optimally $(\mathrm{kW}) ; \mathrm{A}=$ Area of land cultivated (ha).

A was determined for each farm by multiplying areas of cultivated land in hectare for each participating farmer by the total number of farmers, and TH was determined as a function of rate of energy consumption and resting period for different manual operations (plowing, planting, and harvesting).

Parameters for $\mathrm{TH}$ and $\mathrm{LH}$ were determined based on the exact response of the average farmers in the surveyed areas on the estimated resting period in minute per hour of work on each manual operation.

Degree of Mechanization M3 represents the first degree of mechanization, motorized machinery existing (Nowacki, 1974) which indicated as;

$\mathrm{LM}=\mathbf{0 . 2}$. NM.TM/A

where: $\mathrm{LM}=$ Average energy input or work per hectare by motorized machines $(\mathrm{kW}) ; 0.2=$ Corrector coefficient of the tractor-powered machine; $\mathrm{NM}=$ Rated working power of the tractor $(\mathrm{kW}) ; \mathrm{TM}=$ Rated working time of the motorized energy source, (h); A = Area worked in hectare by motorized machines (ha). 


\section{Effective field capacity $(C)$}

$\mathrm{C}=\mathrm{SWEF}(\mathrm{hr} / \mathrm{h}) .36 / 100($ Kepner et al. 1978)

where: $\mathrm{C}=$ Effective field capacity, ha/h; $\mathrm{S}=$ Operating speed, $\mathrm{m} / \mathrm{s} . \mathrm{W}=$ Width of cut of implements, $\mathrm{m}$; EF = Field efficiency, \%;

Rated working time (TM)

$\mathbf{T M}=\mathbf{1} / \mathbf{C}$

\section{Drawbar horsepower(DBP)}

$\mathrm{DBP}=\mathrm{S.D} / 3.6(\mathrm{~kW})$

where: $\mathrm{S}=$ Operating speed, $\mathrm{m} / \mathrm{s} ; \mathrm{D}=$ Draft, representing total force parallel to the direction of travel required to propel the implement $\mathrm{kN}$.

\section{Rated working power of the tractor (NM)}

$\mathrm{Nm}=\mathrm{DBP} / \mathbf{0 . 7 4}(\mathrm{kW})$

where: 0.74 is the average value of the tractive and transmission coefficient on firm soils ranging from 0.73 to 0.75 for $80 \%$ loading as characterized by the textural soil type of the surveyed areas.

\section{2- Determination of mechanization index}

Mechanization index (MI), represents the percentage of work of the tractors in the total of human work and of the machinery. It was calculated according to (Nowacki, 1974);

$\mathrm{WME}=\mathrm{LM} / \mathrm{LT} \cdot \mathbf{1 0 0 \%}$

where: $\mathrm{WME}=$ Mechanization index, \%; $\mathrm{LM}=$ Average sum of all mechanical operation work of the machine, $\mathrm{kW} \cdot \mathrm{h} / \mathrm{ha}$; LT $=$ Sum of all average work outlays by human and tractor powered machines, kW.h/ha.

$\mathbf{L T}=\mathbf{L M}+\mathbf{L H}$

\section{3- Measurement of the productivity of machine and human labor}

Productivity may be conceived as a measure of technical or engineering efficiency of production. The productivity of machine and human labor could be based on production schedule which represent the maximum 
amount of output that can be produced from any specific set of inputs given by the existing technology. The input of labor and capital are the independent variables in the production in terms of a man-hour and in a machine-hour, which are related by (Jhingan, 1997).

$\mathbf{Q}=\mathbf{F}(\mathbf{K}, \mathbf{L})$

where: $\mathrm{Q}=$ the output; $\mathrm{F}=$ functional relationship; $\mathrm{K}=$ the amount of capital; $\mathrm{L}=$ the amount of labor. The productivity of labor, machine, and total productivity were obtained from (Ortiz and Salvador 1980) as presented.

$\operatorname{AM}(h a / k W . h)=1 /$ LM.............................(10)

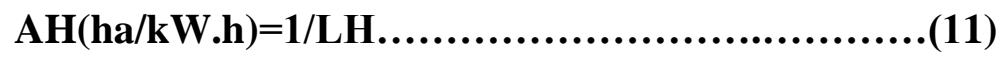

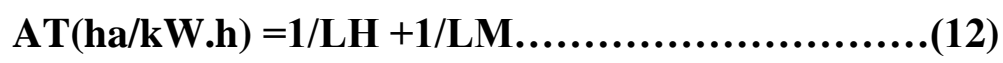

where: $\mathrm{AM}=$ Productivity of machines (ha/kW.h), defined as the work carried out in function of the machinery employed; $\mathrm{AH}=$ Productivity of labor (ha/kW.h), defined as the work carried out in function of labor employed; $\mathrm{AT}=$ Total productivity and all other terms as defined previously (ha/kW.h).

4- Cost benefit ratio for the production of major arable crops (Maize $\&$ Sugar beet) in the surveyed areas

The profitability was determined using gross margin analysis. The benefit cost ratio was obtained from the expression given by (Jhingan 1997).

$(\mathrm{BCR})=\mathrm{TR} / \mathrm{TC}$

where: $\mathrm{CBR}=$ cost benefit ratio value; $\mathrm{TR}=$ Total revenue $\left(\mathrm{P}^{*} \mathrm{Y}\right), \mathrm{P}=$ Price, $\mathrm{Y}=$ Yield tons $/ \mathrm{ha}$ or $\mathrm{kg} / \mathrm{ha}, \mathrm{TC}=$ Total Cost $(\mathrm{FC}+\mathrm{VC}), \mathrm{FC}=$ Fixed Cost, $\mathrm{VC}=$ Cost of the variable inputs. Values of all farm labor were based on the prevailing agricultural wages per day and the prevailing market prices were used for variable inputs and outputs. These were estimated on the probable rates of returns based on the conditions as at the time of the study. 


\section{RESULTS AND DISCUSSION}

\section{Index of agricultural mechanization}

The practice of selective mechanization system was clear in all farms. The mechanical operations were spreaded from seedbed preparation until the harvesting but with majority to tillage operations such as plowing and harrowing. Some other operations like harvesting was manually done. From collected data in table (1), it was obvious that, mechanized seedbed preparation operation was consumed more energy inputs than both other mechanized planting and harvesting operations. This is an indication that the mechanized practice was not visible in modern technique. The study revealed that low production under utilization of mechanical power and uses of old tractors were contributed to low level of mechanization but with relatively the highest mechanization level of $62.99 \%$ for Sugar beet area and least level of $26.53 \%$ for West Nubaria area as shown in Table (2) which presents various work outlays for the investigated power sources (LM: machines, LH: Human labor) were determined for various farms. The operation for tractor power was determined by giving consideration to the implement width of cut (W), operating speed, and machine efficiency. While for human labor, TH, were determined by giving consideration to total resting period per hour of work per day. The index of mechanization for each farm was determined using Equation (2). Data revealed that index of mechanization increase with increasing the human labor productivity, machine productivity and total productivity. This is because great work capacity and more time of utilization of the human work are needed for the same area. Such results were in agreement with the finding of (Olaoye 2007).

Table (1): Energy used for mechanical operations (kW.h/ha)

\begin{tabular}{cccccc}
\hline \multicolumn{6}{c}{ Energy used for mechanical operations in farms (kW.h/ha) } \\
\hline $\begin{array}{c}\text { Mechanized } \\
\text { operation }\end{array}$ & $\begin{array}{c}\text { West } \\
\text { Nubaria }\end{array}$ & El Bostan & $\begin{array}{c}\text { South } \\
\text { El } \\
\text { Tahrir }\end{array}$ & $\begin{array}{c}\text { El } \\
\text { Nahda }\end{array}$ & $\begin{array}{c}\text { Sugar } \\
\text { beet }\end{array}$ \\
\hline Plowing & 10.8 & 9.0 & 6.0 & 9.0 & 9.0 \\
Harrowing & 4.0 & 4.0 & 5.0 & 6.0 & 4.9 \\
Planting & 2.5 & 3.0 & 3.2 & 3.2 & 3.3 \\
Harvesting & 2.1 & 2.4 & 2.4 & 3.5 & 2.5 \\
\hline
\end{tabular}


Table (2): Summary of the level of mechanization in relation to total output power, human productivity, machine productivity and total productivity per unit areas of cultivated land

\begin{tabular}{cccccc}
\hline Farms & $\begin{array}{c}\text { West } \\
\text { Nubaria }\end{array}$ & El Bostan & $\begin{array}{c}\text { South } \\
\text { El Tahrir }\end{array}$ & El Nahda & $\begin{array}{c}\text { Sugar } \\
\text { beet }\end{array}$ \\
\hline $\begin{array}{c}\text { Cultivated Area } \\
\text { (ha) }\end{array}$ & 65593 & 65709 & 138243 & 46795 & 82917 \\
$\begin{array}{c}\text { Total tractor power } \\
\text { (kW) }\end{array}$ & 88.25 & 88.25 & 88.25 & 94.2 & 94.2 \\
$\begin{array}{c}\text { Total human power } \\
\text { (kW) }\end{array}$ & 1.8 & 1.6 & 1.8 & 2.0 & 1.8 \\
$\begin{array}{c}\text { Total output power } \\
\text { (kW) }\end{array}$ & 90.05 & 89.85 & 90.05 & 96.2 & 96 \\
$\begin{array}{c}\text { Level of mechanization } \\
\text { (\%) }\end{array}$ & $\mathbf{2 6 . 5 3}$ & $\mathbf{2 8 . 8 2}$ & $\mathbf{3 1 . 2 3}$ & $\mathbf{4 0 . 0 0}$ & $\mathbf{6 2 . 9 9}$ \\
$\begin{array}{c}\text { Machine productivity AM } \\
\text { (ha/ kW.h) }\end{array}$ & 0.0216 & 0.0316 & 0.0383 & 0.0069 & 0.0158 \\
$\begin{array}{c}\text { Human labor productivity } \\
\text { AH }\end{array}$ & 0.0078 & 0.0128 & 0.0174 & 0.0046 & 0.01064 \\
$\quad \begin{array}{c}\text { (ha/ kW.h) } \\
\text { Total productivity AT (ha/ } \\
\text { kW.h) }\end{array}$ & 0.0294 & 0.0444 & 0.0557 & 0.0115 & 0.0427 \\
\hline
\end{tabular}

\section{Productivity}

Productivity of the machine and labor were determined using Equation (10) to (12). The variability between productivity was compared to the cultivated areas and the mechanization index for each area to identify the contribution and efficiency of the variable input power sources in terms of production. Data on crop yields is a function that depends on the magnitude of the mechanization inputs. The estimation of crop yields ranged from 1.2 to $1.7 \mathrm{Mg} / \mathrm{ha}$ for maize and from 11 to $13 \mathrm{Mg}$ / ha for sugar beet tubers as shown in Table (3). Figure (1) shows that productivity of variable inputs increase proportionately with the increase of farm area. The indication is that the level of economic resources available to farmers determines the production technology for crops and the probability of adopting mechanization technology and effective utilization of energy sources. The highest productivity recorded is 0.0557 ha/kW.h for El-Bostan area with a farm size of 65709 ha and the least was recorded for El Nahda as $0.0115 \mathrm{ha} / \mathrm{kW}$.h for a farm size of 46795 ha. 
Table (3): Economic analysis of crops production.

\begin{tabular}{|c|c|c|c|c|c|}
\hline \multirow{2}{*}{$\begin{array}{c}\text { Farm economic analysis } \\
\text { of production }\end{array}$} & $\begin{array}{c}\text { West } \\
\text { Nubaria }\end{array}$ & $\begin{array}{c}\text { EI } \\
\text { Bostan }\end{array}$ & $\begin{array}{c}\text { South El } \\
\text { Tahrir }\end{array}$ & $\begin{array}{c}\text { El } \\
\text { Nahda }\end{array}$ & $\begin{array}{c}\begin{array}{c}\text { Sugar } \\
\text { beet }\end{array} \\
\end{array}$ \\
\hline & \multicolumn{5}{|c|}{ Sugar beet } \\
\hline Average yield (Mg/ha) & 11.00 & 11.22 & 12.43 & 12.73 & 13.00 \\
\hline $\begin{array}{l}\text { Sale price } \\
(680 \mathrm{LE} / \text { ton })\end{array}$ & 7940 & 8032 & 8540 & 8666 & 8780 \\
\hline $\begin{array}{c}\text { Variable costs of } \\
\text { production ( } \mathrm{LE} / \mathrm{Mg})\end{array}$ & & & 4252 & & \\
\hline $\begin{array}{l}\text { Fixed costs of production } \\
\text { ( LE/ha) }\end{array}$ & & & 2800 & & \\
\hline $\begin{array}{c}\text { Total costs of production } \\
\text { ( LE/ha) }\end{array}$ & & & 7052 & & \\
\hline \multirow[t]{2}{*}{ Cost benefit ratio } & 1.125 & 1.138 & 1.211 & 1.228 & 1.245 \\
\hline & \multicolumn{5}{|c|}{ Maize } \\
\hline Average yield (Mg/ha)) & 1.20 & 1.30 & 1.40 & 1.60 & 1.70 \\
\hline $\begin{array}{c}\text { Sale price } \\
(14000 \text { LE/Mg) }\end{array}$ & 16800 & 18200 & 19600 & 22400 & 23800 \\
\hline $\begin{array}{c}\text { Variable costs of } \\
\text { production ( LE/ha) }\end{array}$ & & & 10910 & & \\
\hline $\begin{array}{l}\text { Fixed costs of production } \\
\text { ( LE/ha) }\end{array}$ & & & 5233 & & \\
\hline $\begin{array}{c}\text { Total costs of production } \\
\text { ( LE/ha) }\end{array}$ & & & 16143 & & \\
\hline Cost benefit ratio & 1.040 & 1.127 & 1.214 & 1.387 & 1.474 \\
\hline
\end{tabular}

๓Machine productivity AM (ha/kW.h) ÐHuman labor productivity AH (ha/kW.h)
घTotal productivity AT (ha/kW.h)

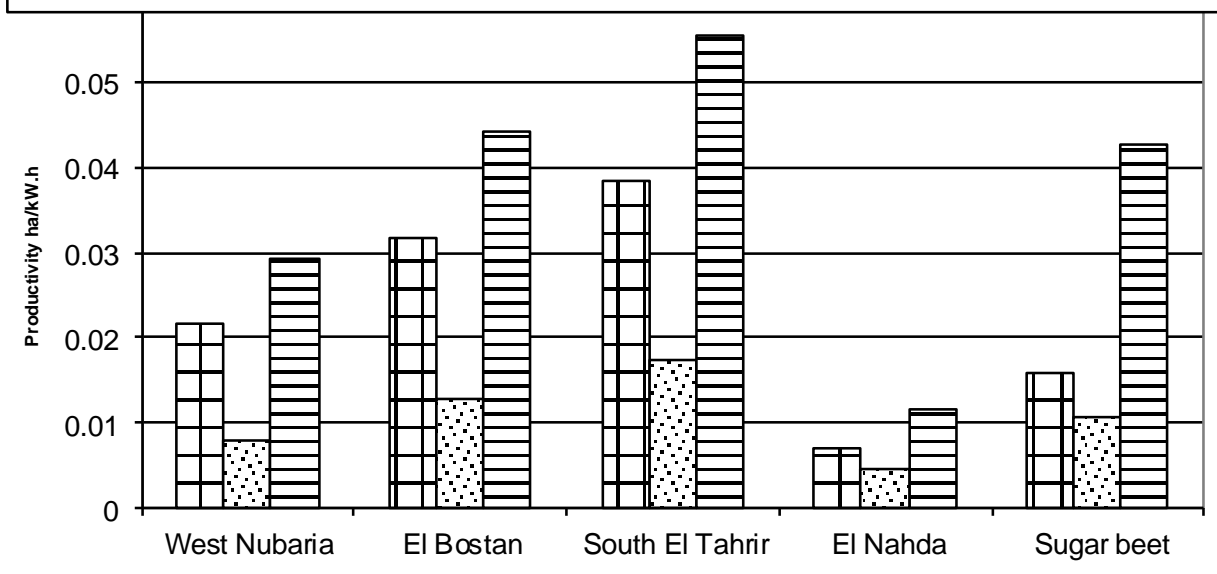

Fig. (1): The relationship between human productivity, machine productivity and total productivity per unit area of cultivated land. 


\section{Level of mechanization}

When mechanization index was performed to estimate the level of mechanisation among five different locations in order to find out different degrees of mechanisation with measures of farm equipment ownership, there were different factors usually affect on mechanization tools. The sugar beet area was highly recorded level of mechanization (62.99\%) due to spreading different machineries, tractors and more accessibility of machinery usage which led to highly yields as compared with other different areas. In contrast West Nubaria area was the lowest recorded level of mechanization (26.53\%) due to less spreading and ownership of different machineries and tractors and less accessibility of machinery usage which led to lowest yields as compared with other different areas. Both of El-Nahda and South El Tahrir areas have a mild degrees of mechanization (40.00 and $31.23 \%$ ) that allows multiple usage of machinery on average production without the need for major investment in mechanization aids. Fig (2) clarify the relation between level of mechanization and benefit cost ratio for both sugar beet and maize. It was obvious the there were a significant relations with $\mathrm{R}^{2} 0.868$ and 0.991 for sugar beet and maize respectively in polynomial equations.

Studying there relations indicate the following:

\section{Sugar beet site:}

Improving the level of mechanization rise the cost benefit ratio by appreciable value specially behind the value of $30 \%$. Further improvement in this value of mechanization enhance cost benefit ratio value but with smaller amounts, that's may be means that sugar beet need essential mechanization tools only to get acceptable cost benefit ratio

\section{Maize site:}

The relation give through a positive correlation between enhancing the level of mechanization and yielded cost benefit ratio. The maximum cost benefit cost ratio is higher in maize than that achieved by maximum level of mechanization in sugar beet, which means more sensitivity of maize to mechanization than sugar beet. The previous relations indicated trusted return (as cost benefit ratio) instead of any costed mechanization. 
Generally for both sites the regression equation could configure to the farmers and investors how much could be gain by any level of applied applications.
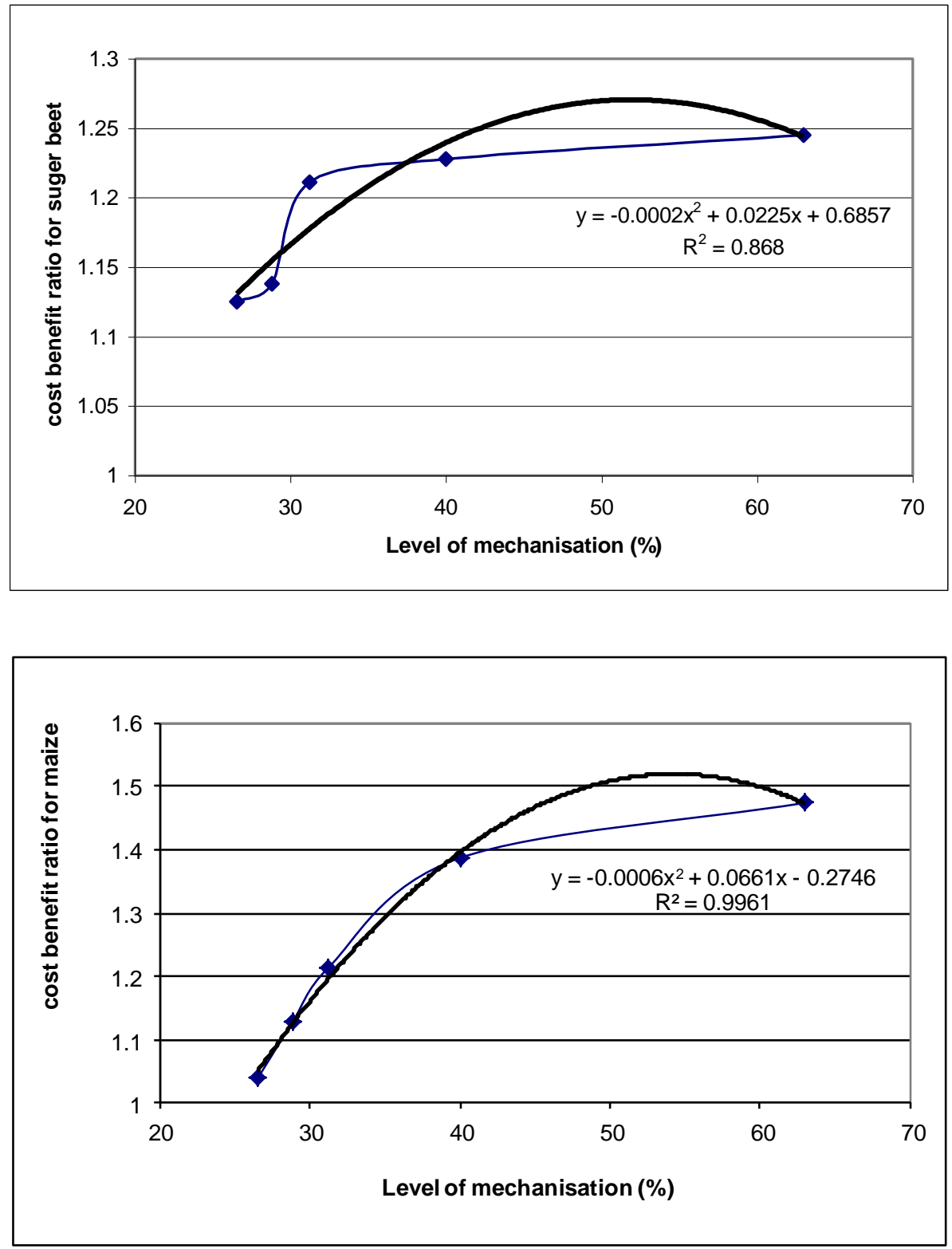

Fig. (2): The relationship between level of mechanization and cost benefit ratio for both sugar beet and maize. 


\section{Cost benefit ratio:}

The costs of each input and gross production values were calculated for each farm production and were given in Table (3). Fixed and variable costs within total production costs were calculated independently from each other. The maximum gross values of production were 8780 and $23800 \mathrm{LE} / \mathrm{Mg}$ for sugar beet and maize respectively in Sugar beet area, while The minimum gross values of production were 7940 and 16800 $\mathrm{LE} / \mathrm{Mg}$ for sugar beet and maize respectively in West Nubaria area to their corresponding prices $(680,14000 \mathrm{LE} / \mathrm{Mg})$. Based on these results, the benefit-cost ratio in the surveyed areas were calculated to be, the maximum benefit cost ratio values were 1.24 and 1.47 for sugar beet and maize respectively in Sugar beet area, while the minimum benefit cost ratio values were 1.12 and 1.04 for sugar beet and maize respectively in West Nubaria. Meanhile, there are significant correlation between the level of mechanizations values and cost benefit ratio, fig(2). This simply means on field applications, that any mechanization needed to cultivate, whatever it costs, it will be finally returned to the farmer.

\section{CONCLUSION}

Evaluation of the level of agricultural mechanization and agricultural productivity of some farms in Nubaria area was carried out. The level of agricultural mechanization was established by deriving a relationship between the various sources of farm power and the level of human involvements. The Agricultural mechanization index was then found for the various sources of farm power and the level of productivity. The results of the farm mechanization index revealed that the highest level of mechanization was $62.99 \%$ for the sugar beet area which had different machineries, tractors and more accessibility of machinery usage which led to highly yields as compared with other different areas. In contrast, West Nubaria area was the lowest recorded level of mechanization (26.53\%) due to less spreading and ownership of different machineries and tractors and less accessibility of machinery usage which led to lowest 
yields as compared with other different areas. The total productivity ranges between $0.0115 \mathrm{ha} / \mathrm{kW} . \mathrm{h}$ and $0.0557 \mathrm{ha} / \mathrm{kW}$.h. The average crop yields on maize ranges between 1.2 to $1.7 \mathrm{Mg} / \mathrm{ha}$ and that of sugar beet ranges between 11 to $13 \mathrm{Mg} / \mathrm{ha}$. The general analysis of the study indicated that selectively mechanized system of arable crops production was economically justified with high benefit cost ratio, correlated with high levels in agricultural mechanization policy due to existence of essential infrastructure and financial credits among other variables that explained the observed high scale of production revenue (sugar beet area) and vice versa (West Nubaria area).

\section{REFERENCES}

Bakhshoodeh M. and Thomson K. (2001). Input and output technical efficiencies of wheat production in Kerman, Iran. Agricultural Economics 24, 307-313.

Chisango T. and Dzama T. (2013). An assessment of agricultural mechanization index and evaluation of agricultural productivity of some fast track resettlement farms in Bindura district of Mashonaland central province: Zimbabwe. International Journal of Social Science and Interdisciplinary Research. Vol. 2 (7) 62-82.

Deng X., Lou Y., Dong S. and Yang X. (2005). Impact of resources and technology on farm production in northwestern China. Agricultural Sys. J. 84,155-169.

Jhingan, M. (1997). Advance economic theory (Micro and Macro Economic). Macmilan Publisher, USA.

Karimi M., Rafiee S., Rajabi Pour A., Khairalipour K. and Shahin S. (2008). A pattern to distribute tractor power from the viewpoint of energy case study: Isfahan province in central region of Iran. American-Eurasian J. Agric. \& Environ. Sci., 3 (4): 526-531 
Kepner, R., Bainer R. and Berger E. (1978). Principles of farm machinery $3^{\text {rd }}$ Edition. AVI Publication Company Inc. Connect, Int. U.S.A.

Nowacki T. (1974). Example of technical economic analysis of mechanized process in various agro-technical conditions: Economic commission for Europe AGRI/MECH/32.

Olaoye, J. (2007). An evaluation of farm power and equipment ownership and management in Niger State, Nigeria. Nigerian J. of Tech. Development, 5 (1 \& 2): $94-102$.

Ortiz C. and Salvador I. (1980). Effects of different mechanization levels in Spanish dryland farms. J. of Agri. Mech. in Asia, $3(5): 31-36$.

Ozpinar S. (2006). Effects of tillage systems on weed population and economics for winter wheat production under the Mediterranean dryland conditions. Soil and Tillage Res. J. 87, 1-8.

Rahman S. and Hasan M. (2008). Impact of environmental production conditions on productivity and efficiency: A case study of wheat farmers in Bangladesh. Journal of Environmental Management 88, $1495-1504$.

Singh, G. (2006). Estimation of a mechanisation index and its impact on production and economic factors: A Case Study in India. Biosystems Engineering 93 (1), 99-106.

Tabatabaeefar, A. and Omid, M. (2005). Current status of Iranian agricultural mechanization. Journal of Agriculture and Social Sciences 1(2), 196-201.

http://www.agricultureegypt.com/ArticleDetails.aspx?CatID=13a8f2e 4-51bc-49bf-820c-302787450640\&ID=fe3f0858-97f $2-4851$-acc 2 0493975177fb . (2011). تقرير احصائى عن المساحات الزراعية بمديرية زر اعة النوبارية 
الملخص العربى

\section{استخدام دليل الميكنة لتقييم استخدام مستوى الطاقة المستهلكة

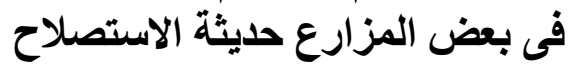

\section{* إسلام محمد منير خاطر}

تم قياس مستويات الميكنة الزراعية في بعض المزارع التى تتتج الذرة وبنجر السكر في المناطق

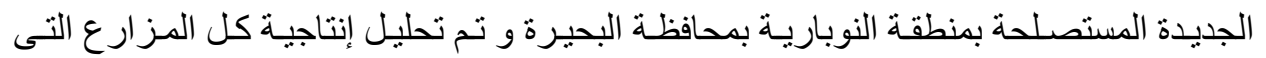
شملتها در اسـة الاستطلاع ـ وكان الغـرض مـن هذه الدراسـة هو تحديد مؤشـر مستوى و قدرة

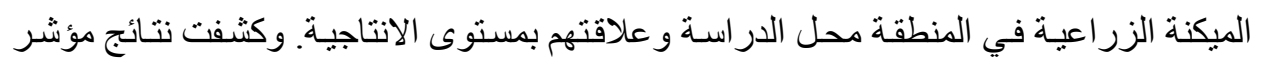

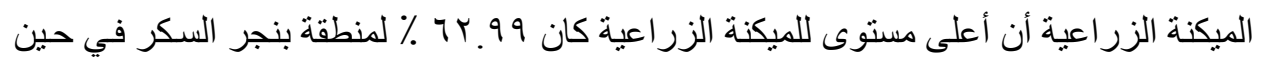

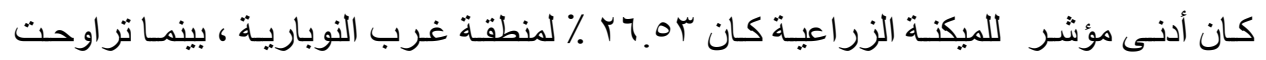

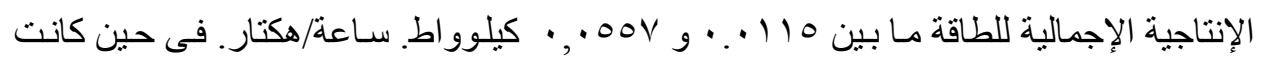

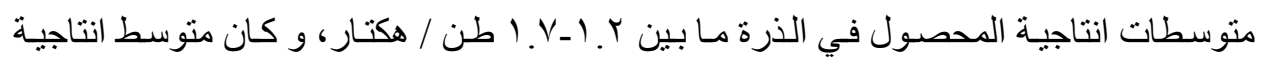

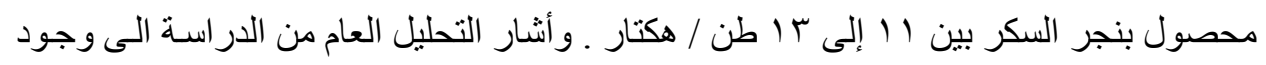

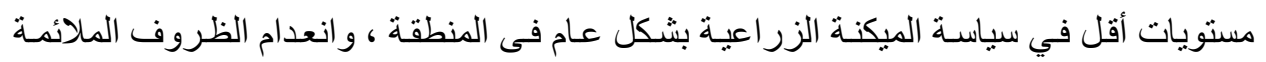
للاندماج الكامل بين الميكنة الزر اعية من ناحية والمز ارعين من ناحية اخرى، و عدم وجود البنية

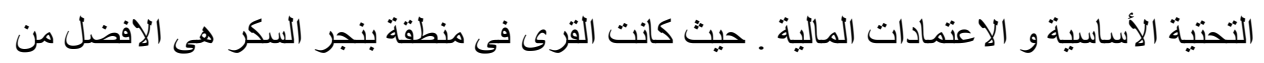

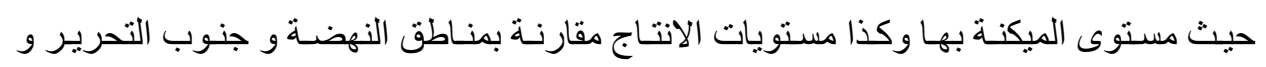

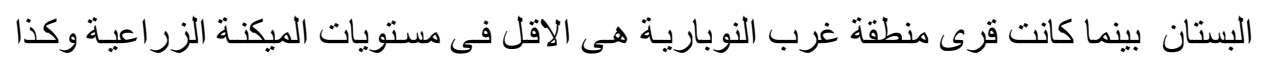

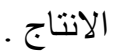

